\title{
Farm labour in California and some implications for Europe
}

\author{
Philip Martin
}

\section{Introduction}

Agriculture was once the largest employer in every society, making most of human history the history of agriculture. The industrial revolution in the mideighteenth century accelerated outmigration from agriculture and prompted governments to regulate wages and working conditions in the nonfarm industries that soon employed a majority of workers. Over time, industrial workers gained protections such as the right to form unions and the right to expect at least minimum wages, overtime pay, and pension and other work-related benefits.

Agriculture was often partially or fully exempted from these labour laws to protect and preserve family farmers. Many governments believed that small farmers could not cope with the complex labour laws that protected employees in factories, and that some hired workers want to become farmers, making them more interested in crop prices than in minimum wages. Even though few hired farm workers are able to climb the agricultural ladder from hired hand to farmer, the notion that many hired workers are farmers in waiting continues to be used to justify incomplete labour law protections for farm workers.

The reason why farm workers become more vulnerable as countries get richer is straightforward: the most capable workers get out of agriculture first, and the 'people left behind' to fill seasonal farm jobs usually lack the education, skills, and connections to get non-farm jobs (President's National Advisory Commission on Rural Poverty 1967). There are many reasons why farm workers find it hard to move up the job ladder and become farmers, including lack of land and capital. Local farm workers are often joined by legal and unauthorised migrants from other areas and countries.

This chapter explains the farm labour prosperity paradox, namely, why hired farm workers become more important and vulnerable as the share of labour employed in agriculture declines. Hired workers do a larger share of work on the fewer and larger farms that produce most farm commodities in richer countries, and they include local workers unable to find non-farm 
jobs and internal and international migrants away from their usual homes. The paradox is discussed by reference to the US, focusing particularly on the Californian agricultural industry, which has the world's most intensive farm system and provides one vision of a future that could emerge in Europe, namely, large and specialised farms that depend on a mix of vulnerable local and foreign workers who have few other job opportunities.

\section{Farmers versus workers}

There is a fundamental difference between farmers and farm workers in most industrial countries. Farmers and their families are businesses whose incomes are the difference between what they receive for the commodities they sell and the cost of producing them. Farm incomes fluctuate with weather, disease, consumer demand, and many other factors, which is why many governments intervene in agriculture to protect the incomes of farmers (Beckman et al. 2017).

Hired farm workers are paid for their work, so they receive wages whether farm prices and incomes are high or low. However, agriculture's biological production process means that most farm workers are employed seasonally, often less than the standard 2,000 hours a year from 40 hours a week for 50 weeks of work. Because farm work is an easy-entry occupation, farm wages are generally lower than non-farm wages, and this combination of lower wages and fewer hours of work translates into lower incomes. In the US, the median hourly earnings of private sector workers are $\$ 25$ an hour, so a fulltime worker earns $\$ 50,000$ a year. Seasonal farm workers are often employed 1,000 hours a year and earn $\$ 12,500$, a quarter as much.

Farmers and farm workers also differ in demographics and political clout. In the US, farmers tend to be older than non-farm workers, are often the third, fourth, or fifth generation to farm, and usually belong to associations that maintain support for agricultural subsidies. Farm workers, on the other hand, tend to be younger than non-farm workers, are often the first generation to do farm work in the country, and are not well represented by unions or other organisations that could protect their interests. A familiar US saying is that it is hard to find a farmer under 40 because of the capital required to operate a farm, and hard to find a farm worker over 40 because of the physical demands of the job.

\section{Vulnerable farm workers}

Despite massive past and ongoing current rural-urban migration, agriculture remains the world's major employer, employing 28 per cent of the world's 3.6 billion workers in 2019 and two thirds of all workers in low-income developing countries (World Bank 2019). All countries with more than 50 per cent of their workforces employed in agriculture are poor, and all countries 
with fewer than five per cent of their workers employed in agriculture are rich or considered to be high income by the World Bank (World Bank 2019).

The share of a country's workers employed in agriculture declines as incomes rise, while the share of farm work done by hired workers increases. There are several reasons why hired workers become more important in richer countries, including the fact that farm production becomes concentrated on fewer and larger farms. The total number of farms may remain stable, as with the roughly two million farms in the US over the past three decades, but an ever-smaller number of farms account for most farm output and employment. For example, in 2017, the largest 10,000 US farms with expenses for farm labour accounted for over half of total farm labour expenditures.

The workers employed on these 'factories in the fields' tend to be more vulnerable than hired farm workers in the past for three reasons. First, the farm workers most capable of protecting themselves are the first to leave agriculture: their ambition, education, and contacts help them to find better non-farm jobs rather than remain in agriculture and try to achieve higher wages. Second, as the domestic supply of farm workers decreases, farmers look further afield for workers, recruiting minorities left behind by economic growth, lawful guest workers, and unauthorised migrants. Hard-to-regulate contractors are often involved in the recruitment, transport, and housing of local minorities and foreign workers, increasing the vulnerability of the workers they bring to farms.

Third, as a competitive industry with many small producers, agriculture is often exempted from or treated differently from other sectors under labour laws and social welfare programmes. Children may be allowed to work on farms. US guidelines from the Department of Labor state that "minors of any age may be employed by their parents at any time in any occupation on a farm owned or operated by his or her parent(s)' (US Department of Labor 2020) and 'children as young as 12 may be employed outside school hours for wages with parental consent or on farms where their parents are employed' (US Department of Labor 2016), and there may be a separate and lower minimum wage for farm workers. Farm workers may not be eligible for or earn access to employment-linked social insurance programmes such as unemployment insurance and workers compensation or some means-tested welfare programmes for poor residents.

This combination of more vulnerable workers, intermediaries, and the incomplete farm labour regulatory and social safety net coverage widens the gap between farm and non-farm labour markets as per capita income rises. Take education. In 1979, the average US hired farm worker aged 25 and older had 10 years of schooling, while the average American adult had 12 years, a two-year gap (Whitener and Coltrane 1981, 6). Today the National Agricultural Workers Survey (NAWS) reports that US crop workers have an average eight years of schooling, six years less than the average 14 years of all US workers (US Department of Labor n.d.). The reason for this widening 
education gap is straightforward: over the past four decades, Mexican-born workers have replaced US-born workers in the farm workforce.

When farm workers are found in poor housing, indebted to recruiters, or working under exploitative conditions, it may seem that agriculture has not broken links with a past that included slavery, serfdom, and other institutions that exploited farm workers.

Farmers often respond to reports of poor working conditions by emphasising that they are offering jobs to workers without other job options, and that the farm workers portrayed in media stories nonetheless return to work for them year after year. There is a widening gap between the often college-educated farm labour reformers who have never done farm work and sometimes see all manual labour as exploitative, and farmers who believe they are offering good jobs to low-skilled workers with few other options.

The best protection for all workers at all times is the power to say no to poor wages and exploitative working conditions. Workers can say no if they have better alternatives. However, empowering workers by providing them with alternative job options leaves unanswered the question of what to do until more development offers better options for farm workers.

\section{Three US farm labour systems}

The US farm labour system has been shaped by two centuries of history, and has produced distinct farm labour systems, each with their particular labour arrangements, including the roles of hired workers. In this section each of these are detailed, however, the focus is on the Californian agricultural system, which came to develop the most intensive agricultural industry in both the US and worldwide.

From the outset, family farms were praised as the ideal at a time when large plantations depended on slaves. The fact that most farms were family farms when labour protection laws were enacted allowed all of agriculture to be exempted, including the large farms that hired most farm workers. The first US Census of Population in 1790 found that 95 per cent of the four million Americans lived in rural areas, and almost all these rural residents were involved in agriculture. The number of people employed in agriculture rose with the westward expansion, but the share of US workers employed in agriculture fell with industrialisation, from 70 per cent in 1840 to 40 per cent in 1900 and to less than two per cent since the 1980s (USDA).

In the early 1800 s, farmers obtained seasonal labour in three major ways (Martin 2003, ch. 2). First, large farm families in the east and midwest produced crops and livestock to satisfy their own needs, and relied on all members of the family to work at peak seasons; children went to school or had leisure time when there was little farm work. There was no reason for family farms in the northeastern states to expand and produce a surplus to sell in the early 1800 s, since there were few cities and transport to them was 
very expensive. New York, the largest US city and the major market for farm commodities, had 60,000 residents in 1800 .

Second, plantations in the south that produced cotton and tobacco for export needed more seasonal labour than even large farm families could provide. They relied on slaves who were owned by masters and were bought and sold. In a country that offered free land, free workers were unwilling to work for low wages on plantations, which needed workers for six to eight months. Plantations could justify the provision of food and housing for slaves year round to ensure that workers were available for planting and harvesting.

Before slavery ended with the Civil War in the 1860s, the prices of land used to grow cotton and the price of slaves to plant and harvest cotton were rising because cotton prices were increasing. There was little fertiliser used on cotton fields in the pre-Civil War south, so areas with older and less productive cotton land, such as Virginia, specialised in producing slaves for areas where cotton acreage was increasing, such as Louisiana and Texas. Conrad and Meyer (1958) conclude that slavery was profitable, as some areas specialised in producing slave labour and others in producing cotton.

Third, farms in the arid western states such as California developed differently. Spanish and Mexican land grants to a favoured elite and church missions created large ranches or ranchos of 50,000 acres or more that grazed cattle and produced wheat. Many large wheat farms were known as bonanza farms, owned by absentee owners who reaped a harvest and a bonanza if winter rains produced a crop. They were expected to be broken into familysized units when the transcontinental railroad, completed on 10 May 1869, made it easier for small farmers to move west as the journey across the US was reduced from months to days, transforming California by integrating the state's economy into that of the other states. Further, the development of irrigation systems in the 1870s made the production of fruit profitable, which was first dried and canned and later sent to market packed in ice to be consumed fresh.

Since fruit production was labour intensive, it was assumed that large wheat farms would have to be broken into family-sized parcels in order to obtain seasonal workers. Contemporary observers expected the emergence of family farms to produce fruit for cooperatives that would market it for them. However, large California farms did not need to be sub-divided into family-sized units because workers with no other job options were available to be seasonal farm workers. Over 15,000 Chinese workers were imported from Guangdong to help to build the transcontinental railroad through the Sierra mountains for $\$ 1$ a day. When the railroad was completed, the Chinese were laid off, and most moved to Sacramento, San Francisco, and other cities rather than returning to China.

The railroad brought cheaper manufactured goods to California from other states, prompting layoffs of white workers as the factories that had 
supplied goods for California residents closed. The Chinese were blamed for this recession, and many were driven out of Californian cities by jobless white workers who accused them of being willing to work for low wages. Farmers did not discriminate, but they also did not pay workers when there was no need for them. Many of the Chinese workers who had been laid off after the railroad was completed became seasonal farm workers. Contemporary observers described them as cheaper than slaves because they 'came with the wind and went with the dust,' that is, they were paid only when they worked (Fuller 1991).

Waves of other migrants without non-farm job options followed the Chinese into the fields and preserved the system of large farms inherited from Spain and Mexico. The Japanese government legalised emigration in 1886, and newcomers from Japan soon replaced aging Chinese workers on Californian farms until a 'Gentlemen's Agreement' between Japan and the US in 1907 stopped more Japanese arriving. Large farmers turned to Punjabis and Filipinos to fill the ranks of the expanding seasonal farm workforce early in the twentieth century. However, most immigration from Asia was halted by federal laws in the 1920 s, prompting growers to encourage Mexicans to move north to become seasonal farm workers. Many Mexicans responded, but during the Depression of the early 1930s, some were 'repatriated' in order to open up jobs for Americans.

During 150 years of labour-intensive agriculture in California which began in the 1870s, there was only one period when most seasonal farm workers were white US citizens. The plains states such as Oklahoma were settled in the 1920s by small farmers who borrowed money to plough native grasses and plant wheat, setting the stage for a Dust Bowl in the 1930s when crops failed and drought whipped up dust storms. Millions of farmers were unable to repay their bank loans, and at least one and a half million people from Arkansas, Oklahoma, and other states moved to California to begin anew, as exemplified by the Joad family portrayed in John Steinbeck's 1939 novel, The Grapes of Wrath.

The US declared war on Germany and Japan in December 1941, and many Dust Bowl migrants were drafted or found jobs in non-farm defence industries. Farmers complained of labour shortages and won a Bracero programme, a series of agreements that admitted almost five million Mexicans between 1942 and 1964 as legal guest workers. Many Mexican Braceros returned year after year, but up to two million Mexicans gained experience working in US agriculture before the programme ended in 1964 as a form of civil rights for Hispanics, a way to put upward pressure on the wages of Mexican-Americans who worked alongside Braceros in the fields.

The availability of workers without options, from the Chinese to Dust Bowl farmers and Mexicans, provided an ample supply of labour that encouraged the preservation and expansion of large farms that were dependent on hired workers. Each new wave of migrants undercut established migrants, 
encouraging experienced farm workers to find non-farm jobs rather than seeking upward mobility in the farm labour market.

\section{Farm worker unions}

The increasing reliance on more farm workers, which on their side often have seen wages and working conditions worsening, has often generated conflicts between interests of capital and labour, both at farms and in society at large. This section outlines how trade unions since the end of the Bracero programme have sought to regulate labour practices, focusing on the Californiabased United Farm Workers.

Until the mid-1960s there were few successful self-help efforts to raise farm wages. However, the end of the Bracero programme ushered in a 15-year golden era for farm workers which ended in the 1980s with rising unauthorised Mexico-US migration. The United Farm Workers (UFW) union won a 40 per cent wage increase for grape harvesters employed by a subsidiary of liquor conglomerate Schenley Industries in 1966, raising the base wage for grape harvesters from $\$ 1.25$ to $\$ 1.75$ an hour at a time when the federal minimum wage was $\$ 1.25$.

There were no government-supervised elections to determine if farm workers wanted to be represented by the UFW because farm workers were excluded from the National Labor Relations Act of 1935, the basic law granting workers the right to form or join a union or refrain from union activities. Organising in the 1960s meant that the UFW sent contracts to growers saying that their workers wanted UFW representation and asking growers to sign the contract or face a boycott of their commodity.

After many police interventions to break up disputes between growers and the UFW, state leaders agreed in the 1970s that farm labour disputes had to be moved from the streets into bargaining and court rooms. Governor Jerry Brown signed into law the Agricultural Labor Relations Act (ALRA) in 1975, making California the first state to grant farm workers the right to organise and bargain with farm employers. The ALRA and unions were expected to usher in a new era of farm labour, with most farm workers represented by unions and farm worker becoming an occupation akin to construction worker, offering high hourly wages when there was work and unemployment insurance benefits during the off season (Martin 2003).

However, the golden era for farm workers ended in the early 1980s, as unauthorised Mexico-US migration rose. The demise of the UFW since its high watermark in 1979 has been the subject of countless books and articles. There are four major explanations for why Cesar Chavez and the UFW failed to transform seasonal farm work from a job into a career (Martin 2003). The first centres on Chavez's flaws, explaining that he wanted to lead a poor people's movement rather than a union and was dismayed to realise that most farm workers wanted a middle-class lifestyle, not a perpetual struggle for a 
new society (Pawel 2009). The UFW lost most of its lawyers when Chavez insisted that they move from Salinas, the US salad bowl, to the UFW's mountain headquarters southeast of Bakersfield.

The second explanation for the UFW's demise focuses on state politics. The ALRA is one of the most pro-worker and pro-union laws in the US, with detailed election procedures that permit quick elections before seasonal workers move to other farms and providing extra remedies if employers fail to bargain with a certified union in good faith. The ALRA was enacted under Democrats, who also made the first appointments to the ALRB. When Republicans began to make ALRB appointments in the 1980s, the UFW charged that the state agency was biased against farm workers and refused to cooperate with it.

The third explanation for the demise of the UFW involves the changing structure of agriculture, that is, who owns farmland, who operates farms, and who hires workers. UFW boycotts were most effective against conglomerates with farming subsidiaries. For example, Schenley was a NY liquor firm based in the Empire State Building, one of the big four which also included Seagram, National Distillers, and Hiram Walker. UFW supporters picketed liquor stores selling Schenley whiskey during the Christmas buying season in 1965, reducing sales and prompting Schenley leadership to agree to a UFW table grape contract over the objections of Schenley's California farm managers.

UFW boycotts and the agricultural crisis of the 1980s, when commodity and land prices fell, prompted many conglomerates with agricultural operations to sell their farmland. Oil firms such as Shell and Tenneco, Hawaii land developer Amfac, and other conglomerates that earned most of their profits from non-farm businesses sold land to farmers who were not as susceptible to boycotts. These farmers, in turn, often relied on farm labour contractors to obtain workers, and farm labour contractors (FLCs) whose crews had prounion leanings found it hard to find farmer clients.

Chavez anticipated that FLCs would compete with unions, and insisted that the ALRA make the farm operator the employer of workers brought to farms by FLCs for union purposes. The ALRA makes farmers, rather than FLCs, the employers of workers which FLCs bring to farms, so that an FLC employee who was employed on 10 farms could work under 10 different union contracts. However, Chavez did not anticipate that many FLCs would bring both equipment and workers to farms and thus be considered custom harvesters who were the sole employers of the workers they brought to farms under all labour laws, including tax, labour, and immigration. Employees of custom harvesters may work on 10 farms, but they would have only one union contract if their custom harvester employer was unionised.

The fourth explanation for the demise of the UFW was rising unauthorised Mexico-US migration. The UFW called a strike against lettuce growers in 1979, as its first contracts with vegetable growers - which were signed 
under the ALRA - were expiring, to support a demand for a 40 per cent wage increase, to raise the minimum wage in UFW contracts from $\$ 3.75$ to $\$ 5.25$ an hour. The late 1970s were a period of high inflation, and President Carter asked employers and unions not to raise wages more than seven per cent, the wage increase that was offered by farmers. The UFW feared that unauthorised Mexicans would enter the US and replace strikers in the fields, and so they mounted 'wet patrols' along the border which involved UFW supporters armed with bats trying to prevent unauthorised entries.

The UFW won, but at a high price. Sun-Harvest, the vegetable division of United Brands (Chiquita bananas), and other large vegetable farmers agreed to the UFW's demand for a $\$ 5.25$ minimum wage in new contracts, but then went out of business, leaving workers without a contract as new owners changed commodities and farming methods. Pawel (2009) suggests that Chavez called the strike because of the UFW's inept handling of its health insurance plan, which made lettuce workers angry with the UFW when their health care bills were not paid. Chavez hoped that a large wage increase would stifle worker anger, but the strike boomeranged and helped growers who shipped lettuce. The strike reduced lettuce shipments from the Imperial Valley but, with less lettuce sent to market, the price tripled, and the winter lettuce crop was worth twice as much in 1979 as in normal years.

By the mid-1980s, the UFW had stopped trying to organise farm workers and had a dwindling number of contracts. Unauthorised newcomers from Mexico replaced aging Mexican-Americans who founded and marched with the UFW in the 1960s and 1970s. Mexican newcomers often associated Cesar Chavez with the famous Mexican boxer rather than the leader of a protective union. The UFW during the 1960s organised mostly US citizens. Today, over half of farm workers are unauthorised persons born in Mexico. As with previous newcomers who took farm jobs because they had no other US options, many of the unauthorised Mexicans would like to find non-farm jobs, and most who are parents of US-born children expect their children to complete high school and find non-farm jobs.

Mexico-US migration for farm work peaked in 2000, when a quarter of the hired workers employed on US crop farms were newcomers, defined as persons who were outside the US the year before they were interviewed. Unauthorised Mexico-US migration declined after the 2008-2009 recession, so that fewer than two per cent of crop workers today are unauthorised newcomers.

\section{Contemporary US farm labour}

There were two million US farms in 2017, according to the Census of Agriculture (COA). There were more farm producers, 3.4 million in 2017, than farms because the COA for the first time allowed respondents to designate more than one producer per farm. However, only two million of these producers were primary producers, and the average age of primary producers 
was 59. US farms are concentrated in the midwest and south: Texas had 12 per cent of all US farms in 2017.

The story of US agriculture involves the persistence of small farms despite the consolidation of farm production on fewer and larger farms. One measure of changing farm size is midpoint acreage, the acreage at which half of the production of a commodity is from larger farms and half is from smaller farms. For example, half of all cropland and harvested cropland was on farms with 1,200 or more acres in 2012, up from a midpoint of 600 acres in 1982 and 800 acres in 1997. Some 30,200 farms had more than 2,000 acres of harvested cropland (McDonald et al. 2018).

The consolidation of production on large and specialised farms increases the demand for hired farm labour. Rising labour costs may become another factor encouraging the concentration of production on fewer and larger farms, since large farms can spread the fixed costs of guest workers over more acres or workers, lowering per unit costs.

There are several measures of farm employment. The Bureau of Labor Statistics estimates the average employment of self-employed and wage and salary workers in agriculture. Average employment is derived from monthly or quarterly snapshots of employment, summed, and divided by 12 months or four quarters.

The US had an average of 850,000 self-employed farmers and family members in 2016, and an average of 1.5 million wage and salary farm workers (Table 13.1). The average self-employment of farmers and family members declined by five per cent between 2006 and 2016, and is projected to decline by another three per cent by 2026. In contrast, there was significant growth in the average employment of hired workers between 2006 and 2016, up 23 per cent, and BLS projects stable hired worker employment through 2026. This means that hired workers should account for two thirds of average employment in US agriculture by 2026 .

Table 13.I US agricultural employment (including forestry, fishing, and hunting), 2006-2026. I,000s

\begin{tabular}{lccccc}
\hline & 2006 & 2016 & 2026 & $\begin{array}{l}\text { Change } \\
2006-16\end{array}$ & $\begin{array}{l}\text { Change } \\
2016-26\end{array}$ \\
\hline Hired workers on (wage and & 1,219 & 1,501 & 1,518 & $23 \%$ & $1 \%$ \\
salary) & 893 & 850 & 828 & $-5 \%$ & $-3 \%$ \\
$\begin{array}{l}\text { Self-employed } \\
\text { Total employment in agriculture }\end{array}$ & 2,112 & 2,351 & 2,346 & $11 \%$ & $0 \%$ \\
Share hired workers & $58 \%$ & $64 \%$ & $65 \%$ & & \\
\hline
\end{tabular}

Source: US Bureau of Labor Statistics, table I: employment by major industry sector, which is employment during the payroll period that includes the 12 th of the month, summed, and divided by 12 months. Average employment is not a count of jobs or unique workers; both exceed average employment. (www.bls.gov/opub/mlr/2017/article/projections-overview-and-highlights2016-26.htm.) 
Crop agriculture employs three fourths of hired workers and offers many seasonal jobs, so there are peaks and troughs in hired worker employment. The total number of workers employed in agriculture over a year exceeds average employment, making the number of farm workers a multiple of average employment. In California, there are about two farm workers employed sometime during the year for each year-round equivalent job, a two-to-one worker-to-job ratio (Martin, Hooker, and Stockton 2018).

Some 16,150 California agricultural establishments (NAICS 11) hired an average 425,500 workers and paid them $\$ 13.7$ billion in 2016. Average employment of 425,500 reflects hired worker employment on each farm for the payroll period that includes the 12th of the month; the monthly data are summed and divided by 12 months to generate average employment. Average employment misses workers who were employed sometime during the month, but not during the payroll period which includes the 12th. However, total wages of $\$ 13.7$ billion were the wages paid to all workers, including those who were employed at other times of the month but not during the payroll period that includes the 12th (Martin, Hooker, and Stockton 2019).

All Social Security Numbers (SSNs) reported by agricultural employers when paying unemployment insurance taxes are considered farm workers. While some of those employed for wages on California farms are paid managers of corporate farms, office workers on such farms, and professionals including disease specialists, the large majority of those reported are manual workers. Their California jobs can be tabulated, so that workers with several employers can be assigned to the commodity or NAICS in which they had their highest earnings. This procedure identified 804,200 primary farm workers, and those with their highest wages from an agricultural employer were 81 per cent of the total 989,500 SSNs with at least one farm job. Primary farm workers had their highest earnings from an agricultural rather than a non-farm employer, while primary vegetable workers had their highest earning jobs with a vegetable farmer.

Analysis of the Quarterly Census of Employment and Wages data highlights three major items. First, the total farm workforce exceeds average employment in agriculture by at least two to one in California, which means that seasonal agriculture depends on a pool of workers who are employed only part of the year. There are many industries that offer seasonal jobs and assume workers will be available to fill them, from teaching to sports, and there are many occupations in which workers are employed full time but perform their job for only part time, from firefighting to the military. Agriculture is almost unique in assuming workers will be available when needed at roughly the minimum wage, which is why economist Varden Fuller (1991) asserted that crop agriculture depends on 'poverty at home and misery abroad' to assure itself a seasonal workforce.

Second, there is a gap between what a full-time worker would earn in a particular commodity and the average earnings of workers who were employed in 
Table I3.2 Full time and actual average pay of California farm workers, 2016

\begin{tabular}{|c|c|c|c|c|c|c|}
\hline & & $\begin{array}{l}\text { Employment } \\
\text { (FTE) } \\
\text { Percentages }\end{array}$ & $\begin{array}{l}\text { Pay(\$) } \\
\text { (In full-time } \\
\text { equivalents) }\end{array}$ & $\begin{array}{l}\text { Pay }(\$) \\
\text { (From } \\
\text { primary } \\
\text { empl.) }\end{array}$ & $\begin{array}{l}\text { Primary/ } \\
\text { FTE }\end{array}$ & $\begin{array}{l}\text { Hourly } \\
\text { wage } \\
(\$)^{*}\end{array}$ \\
\hline NAICS II & All agriculture & $100 \%$ & 32,316 & 16,142 & $50 \%$ & 15.54 \\
\hline NAICS III & Crops & $41 \%$ & $34,4 I I$ & 20,540 & $60 \%$ & 16.54 \\
\hline NAICSIIII & Vegetables & $8 \%$ & 39,809 & 26,092 & $66 \%$ & 19.14 \\
\hline NAICSIIII & Fruits & $23 \%$ & 31,846 & 16,900 & $53 \%$ & $|5.3|$ \\
\hline NAICSIII4 & Nursery & $6 \%$ & 35,250 & 27,124 & $77 \%$ & 16.95 \\
\hline NAICS II 2 & Animals & $7 \%$ & 37,372 & 30,989 & $83 \%$ & 17.97 \\
\hline NAICS II 2120 & Dairy & $4 \%$ & 36,864 & 31,433 & $85 \%$ & 17.72 \\
\hline NAICS II5I & Crop support & $51 \%$ & 29,956 & 12,297 & $41 \%$ & 14.40 \\
\hline NAICS II5II3 & $\begin{array}{l}\text { Machine } \\
\text { harvesting }\end{array}$ & $2 \%$ & 35,457 & $|7,57|$ & $50 \%$ & 17.05 \\
\hline NAICS II5II4 & $\begin{array}{l}\text { Other } \\
\text { postharvest }\end{array}$ & $10 \%$ & 40,846 & 23,485 & $57 \%$ & 19.64 \\
\hline NAICS II5II5 & FLCs & $34 \%$ & 24,589 & 9,026 & $37 \%$ & 11.82 \\
\hline
\end{tabular}

Notes. NAICS $=$ North American industry classification system. FTE = full-time employment. FLCs = farm labour contractors. Hourly wage (last column) is calculated by dividing the estimated pay for full-time employment by 2080 (hours).

Source: Martin et al. 2019

that commodity (Table 13.2). The average pay of full-time equivalent workers whose maximum earnings were from agricultural employers in 2016 would have been $\$ 32,300$. However, the actual average earnings of such primary farm workers were $\$ 16,100$, half as much. A full-time worker is employed 40 hours a week for 52 weeks or 2,080 hours, so the implied hourly wage of a full-time worker in California agriculture was $\$ 15.54$. However, most workers are employed fewer hours and/or at lower hourly earnings, which explains why they earn half as much or $\$ 16,100$ (employers do not provide hours worked data).

Third, the gap between full-time equivalent and actual average earnings varies by commodity. Hired workers in animal agriculture earn over 80 per cent as much as full-time workers would earn because most are employed for long hours on one farm. Many large California vegetable farms operate in several areas to supply lettuce and other leafy green vegetables year round, and some of the workers they hire move with the harvest, explaining why the average directly hired vegetable worker earns two thirds as much as a full-time vegetable worker would earn.

The largest sector of employment, farm labour contractors, had the largest gap between full-time and actual average earnings. FLCs employed one third of all primary farm workers in 2016. A full-time worker hired by a FLC would have earned $\$ 24,600$ in 2016 , equivalent to $\$ 12$ an hour. However, 
workers whose maximum earnings were with FLCs earned an average $\$ 9,000$, or 37 per cent as much, equivalent to 900 hours of work at the then minimum wage of $\$ 10$ an hour or 750 hours at $\$ 12$ an hour. This gap between full-time equivalent and average actual pay reflects some combination of fewer hours and lower hourly earnings (Martin 2017a).

\section{Responding to fewer unauthorised migrants}

The combination of fewer unauthorised newcomers and state-mandated increases in minimum wages, federal health care insurance mandates and costs, and state requirements that employers pay overtime premium wages to farm workers has encouraged the subset of farmers who rely on hired workers to make adjustments to cope with rising labour costs. These farm employer adjustments embody 4-S strategies, namely, satisfy current workers, stretch current workers with mechanical aids that increase their productivity, substitute machines for workers where possible and switch to less labour-intensive crops, and supplement current workforces with H-2A guest workers.

Satisfying and stretching workers are short-term responses to rising labour costs. Mechanisation, crop switching, guest workers, and produce buyers turning to imports are longer-term responses. Farmers producing commodities where labour costs are 25 to 40 per cent of variable production costs are weighing their alternatives, including investing in machines to do work now done by hand, building housing for $\mathrm{H}-2 \mathrm{~A}$ guest workers, and forming partnerships to produce in lower-wage countries.

The US farm workforce is becoming more Mexican and more legal, largely because the $\mathrm{H}-2 \mathrm{~A}$ programme is expanding rapidly. Mexican-born workers are 70 per cent of all hired workers on US farms, and over 95 per cent of H-2A workers were born in Mexico. In 2019, half the Mexican-born workers employed on US farms are unauthorised and 15 per cent are legal guest workers (US Department of Labor n.d.).

Farm workers remain on the bottom rungs of the US job ladder, but over the past half century in US farm labour there has been a growing gap between the characteristics of farm and non-farm workers. Until the 1980s, most farm workers were US citizens. Today, with most farm workers being unauthorised Mexicans or legal Mexican guest workers, vulnerability has increased because unauthorised Mexicans can be removed by immigration authorities and legal Mexican guest workers must leave if they lose their US jobs.

\section{The farm labour problem, and its solutions}

The share of a country's workers employed in agriculture declines as a country's per capita income rises. As countries get richer, the production of farm commodities becomes concentrated on fewer and larger farms that rely on hired or wage workers to do most of their work. The farm labour problem, 
dealing with workers who occupy the bottom rungs of the job ladder, does not disappear as the share of labour in agriculture declines. Instead, protecting and assisting hired farm workers becomes more difficult because the composition of the workforce changes. Local or citizen workers who seek farm worker jobs are typically those who lack the skills and contacts to find nonfarm jobs, and they are joined by migrants from other countries with a variety of legal statuses.

\section{From farm jobs to farm work careers}

One universal feature of farm work is that, for most workers, seasonal farm work is a job rather than a career. Most farm workers are looking for 'better jobs,' including jobs that offer higher wages, more hours of work, or respect from supervisors. Most seasonal farm workers hope that their children will not follow them into the fields. This makes the seasonal farm labour market akin to a revolving door, with local workers unable to find better jobs and newcomers from abroad entering the farm workforce, remaining for a decade or less, and exiting for non-farm jobs or because of the physical demands of farm work. There is an asymmetry between farmers, who often proudly proclaim that they are following in the footsteps of their parents and grandparents, and farm workers, who are usually the first generation to do farm work for wages in a rich country.

There have been many efforts to transform hired farm work from a job into a career, and there are some success stories. Many of the workers employed in animal agriculture are local citizens and legal migrants who prefer outdoor work and rural living to non-farm jobs. Employers often offer year-round workers housing and other benefits, and get to know the workers who live and work with the farmer and his/her family.

Converting seasonal farm work from a job into a career has proven to be much tougher. With the production of labour-intensive commodities concentrated on fewer and larger farms, many seasonal workers are hired as interchangeable members of crews that range in size from 20 to 60 . Crews are often brought to farms by intermediaries such as contractors, and most workers do not work alongside or get to know the farm operator on the farm on which they work. Their employer is the intermediary and, since fields and orchards are similar, workers do not care too much who operates the particular farm on which they are working on a given day. There are exceptions, as with cases of workers employed alongside farmers and their families on smaller farms, but such farms account for a small share of production and employment.

\section{Mechanisation, migrants, and imports}

Rich countries face three major options in order to have fresh fruits and vegetables: mechanisation, migrants, and imports (Martin 2017b). 
Mechanisation eliminates the demand for hired farm workers. Agricultural history is the story of machines replacing hand labour, and the declining cost of robotics promises a new wave of labour-saving innovations. For example, precision planting allows machines or sprayers to remove materials other than plants, since weeding machines know where plants are located. Similarly, planting and training dwarf fruit trees to develop fruiting walls expedites the machine picking of apples and other fruits. Soft fruits such as strawberries pose the toughest challenges, but forecasters predict that by 2030 half or more of fresh strawberries will be machine harvested.

The second major option is more migrant farm workers. Most rich countries have programmes that admit foreigners to fill farm jobs, with governments using a variety of techniques to determine how many guest workers to admit, what wages and work-related benefits must be provided to guest workers and any local workers who work alongside them, and what happens to guest workers when the season ends. The trend in most countries has been to give more power to employers to shape guest-worker programmes as the share of local farm workers declines.

The third option is to import more labour-intensive commodities from lower-cost countries. In order to supply fresh produce to consumers year round, most countries import fruits and vegetables when there is little or no local production. Investments in developing countries that have counterseasonal climates and lower wages have extended what was previously only off-season production, so that countries such as Mexico which once exported fresh tomatoes seasonally now export tomatoes year round (Mexico is the world's largest tomato exporter).

Mechanisation, migrants, and imports are interdependent in the sense that faster rising labour costs give a boost to investment in machines and imports, while lower wages for guest workers encourage a continuation of labour-intensive production in the country where produce will be consumed. Over decades, most richer countries are likely to favour mechanisation and imports, but the speed at which they approach a more mechanised and more import-dependent agriculture depends in part on government trade and migration policies.

\section{Implications for Europe}

Agricultural production in both Europe and the US is being concentrated on fewer and larger farms which hire most of a country's farm workers. They have in common a larger than ever reliance on farm workers from poorer countries.

However, there are still four significant differences between US and EU agriculture that have implications for hired farm workers. The first is scale: the US has fewer and larger farms. The US has two million farms that produce farm commodities worth $\$ 400$ billion a year, while the 10 million EU farmers 
produce a similar $\$ 400$ billion worth of crops and livestock. The average farm is larger in the US and fewer than five per cent of the nation's two million farms account for two thirds of total farm production and employment. While it is hard to compare farm structure by commodity, Europe has few of the California-style factories in the fields that employ 5,000 to 10,000 workers during peak harvest periods, but has more production from smalland medium-sized farms, and more hired worker employment on such farms.

The second major transatlantic difference involves hired farm workers. Most of the newcomers to the US farm workforce over the past half century have been unauthorised foreigners. In Europe, the switch from local residents who worked seasonally and internal migrants occurred later and involved a much higher share of legal foreign workers. While most migrant farm workers on US farms are unauthorised Mexicans, most migrant workers on European farms are legal migrants from poorer EU countries who take advantage of freedom of movement regulations to earn higher wages in richer EU countries, such as eastern Europeans who moved to Britain, Germany, Italy, and Spain after the EU enlargements in 2004 and 2007 to fill farm jobs.

Third, on both sides of the Atlantic, intermediary contractors or gangmasters play key roles in organising and deploying crews of workers, which may limit direct communications between farm operators and hired farm workers. However, the US and especially California are ahead of Europe in relying on nonfarm intermediaries to bring more workers to farms. For the past decade, more farm workers have been brought to California farms by nonfarm intermediaries, mostly farm labour contractors, than were hired directly by farmers, so that a typical crew working in a field or orchard was not hired by the farm operator where the workers are employed. European experience with the exploitation of crews of eastern Europeans in the UK, or Africans in southern Italy, highlight the difficulty of protecting workers who are brought to farms by intermediaries. Worker abuse seems most prevalent in labour-intensive agriculture in countries with large informal labour markets, such as Greece, Italy, and Spain (Corrado et al. 2016).

Finally, most US labour-intensive agriculture is in metro rather than rural areas. The US has about 3,100 counties, and those with at least one urban area of 50,000 or more are considered metro counties; 80 per cent of Americans live in metro counties. The 384 metropolitan statistical areas that include groups of metro counties ranging from New York City with 20 million people to Carson City in Nevada with 55,000 people include almost all US labourintensive fruit, vegetable, and greenhouse production and farm workers. US farm worker issues often raise urban rather than rural concerns, such as the high cost of housing.

Despite differences across the Atlantic, the US experience represents important insights for Europe's agricultural industries and their farm labour practices. California, which houses the world's most intensive farm system, provides one vision of a future that could emerge in Europe, namely, large 
and specialised farms that depend on a mix of vulnerable local and foreign workers, who have few other job opportunities.

\section{Acknowledgements}

The author wishes to thank the anonymous reviewers for their comments on the manuscript.

\section{References}

Beckman, J., J. Dyck and K.E.R. Herman. 2017. The Global Landscape of Agricultural Trade, 1995-2014. Economic Information Bulletin Number 181. Washington D.C.: United States Department of Agriculture.

Conrad, A. and J. Meyer. 1958. 'The Economics of Slavery in the Ante Bellum South.' Journal of Political Economy 66: 95-130.

Corrado, A., C. de Castro and D. Perrotta, eds. 2016. Migration and Agriculture Mobility and Change in the Mediterranean Area. London: Routledge.

Fuller, V. 1991. 'Hired Hands in California's Fields.' Giannini Foundation Special Report 91-1. http://giannini.ucop.edu/publications/historic/special-reports.

Martin, P. 2003. Promise Unfulfilled: Unions, Immigration, and Farm Workers. Ithaca: Cornell University Press.

Martin, P. 2017a. Merchants of Labor: Recruiters and International Labor Migration. Oxford University Press.

Martin, P. 2017b. 'The Race in the Fields: Imports, Machines and Migrants.' California Agriculture 72. No 2.

Martin, P., B. Hooker, M. Stockton. 2018. 'Employment and Earnings of California Farm Workers in 2015.' California Agriculture 72.

Martin, P.B. Hooker and M. Stockton. 2019. 'Ratio of Farmworkers to Farm Jobs in California Increased to 2.3 in 2016.' California Agriculture 73: 73-78.

Pawel, M. 2009. The Union of Their Dreams: Power, Hope, and Struggle in Cesar Chavez's Farm Worker Movement. Bloomsbury. http://miriampawel.com/

President's National Advisory Commission on Rural Poverty. 1967. 'The People Left Behind.'

US Department of Agriculture. (n.d.) Farm Labor. Economic Research Service. www. ers.usda.gov/topics/farm-economy/farm-labor/background.aspx.

US Department of Labor. 2020. Agricultural Employment. www.dol.gov/general/ topic/ youthlabor/agriculturalemployment

US Department of Labor (2016) Child Labor Bulletin 102 Child Labor Requirements in Agricultural Occupations Under the Fair Labor Standards Act. www.dol.gov/ sites/dolgov/files/ WHD/legacy/files/childlabor102.pdf.

US Department of Labor (n.d.) NAWS. National Agricultural Workers Survey. www. dol.gov/agencies/eta/national-agricultural-workers-survey.

Whitener, L. and R. Coltrane. 1981. 'Agricultural labour needs in the 1980s.' Report. UD Department of Labor. DOI:10.22004/ag.econ.276698

World Bank. 2019. Employment in Agriculture (\% of Total Employment Modeled ILO Estimate) https://data.worldbank.org/indicator/SL.AGR.EMPL.ZS. 